\title{
La música y la imagen. Anotaciones a partir de El Artista
}

\section{Frère Affanni, Tomás}

\section{Capítulo I}

Por lo general, los trabajos académicos que abordan películas contemporáneas no suelen centrarse en las producidas por el mainstream hollywoodense, lo cual representa, a mi juicio, un grave error. Si la tarea de un director que no pretenda repetir lo ordenado por Hollywood es la de deshacer los clichés de la gran industria cinematográfica, ¿cómo podría ser esto llevado a cabo sin conocer esos clichés contra los que se lucha? ¿Cómo pretender la alteración de un lenguaje común sin adentrarse en los tópicos de ese lenguaje común? Este artículo toma como punto de partida una película muy comentada que, a pesar de ser

Cuadernos del Centro de Estudios de Diseño y Comunicación N ${ }^{\circ} 54$

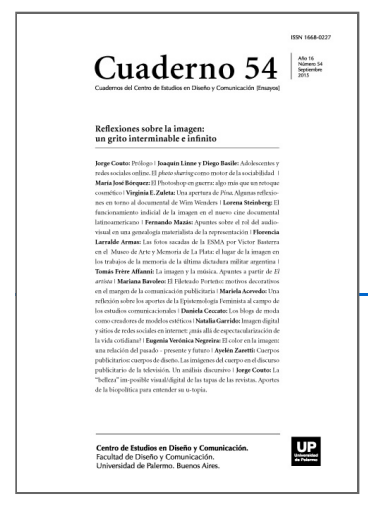

ISSN: 1668-0227

Reflexiones sobre la

imagen: un grito

interminable e infinito

Año XVI, Septiembre 2015, Buenos

Aires, Argentina | 248 páginas

descargar PDF

ver índice de la publicación

Ver todos los libros de la publicación

compartir en Facebook

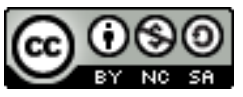

Esta obra está bajo una Licencia Creative

Commons Atribución-NoComercialCompartirlgual 4.0 Internacional

francesa, ha sido recibida por la crítica

norteamericana como una hija propia, obteniendo varios premios tanto en los Oscar como en los Globos de Oro. La peculiaridad de L'artiste (El artista), dirigida por Michel Hazanavicius en 2011, y lo que a su vez le permite ganar el Oscar sin estar hablada en inglés, es precisamente la premisa con la que sus productores la instalaron como producto de consumo masivo: se trata, nos dicen, de una película muda, de un homenaje a la primera época del cine.

En realidad, la falsedad de esto es evidente: El artista no simula o, en todo caso, simula mal, ser una película de la época muda (el argumento más obvio es que centra su acción en el período abierto luego de 1929). El artista es una película de 2011 que utiliza herramientas del cine mudo (o, en realidad, renuncia o usa de otro modo herramientas del cine sonoro), quizás para ser vista como si fuera de otra época. Pero tiene a su mano otras herramientas además de las del cine mudo; el cine de la época silente, en cambio, no tenía otra posibilidad que ser como era. La diferencia es fundamental.

El film comienza en 1921, momento en que el actor George Valentin es una gran estrella del cine (mudo); sin embargo, su éxito se verá primero amenazado, y luego destruido, por la llegada del sonido sincronizado. A partir de esta aparición, y mientras su carrera se opaca, empieza a ascender la de una actriz que él ayudó a descubrir 
en sus años de mayor éxito: Peppy Miller, quien pronto se convertirá en una estrella indiscutible de la industria cinematográfica.

He aquí los rasgos esenciales del argumento de la película. Sin embargo, lo que más me interesa a los fines de este trabajo es trabajar sobre lo que El artista permite como punto de partida, gracias al hecho de prescindir de la voz y de los sonidos diegéticos: el film coloca en el centro de la escena un problema que aparece desde hace siglos en el campo de la música, esto es, el problema de las relaciones entre la música y la imagen o, de forma más amplia, entre el plano sonoro y todo aquello que no corresponde a dicho plano. A través del análisis del tratamiento que esta película hace de la música pretendo avanzar en algunas conceptualizaciones acerca del problema mencionado.

\section{Capítulo II}

Puede decirse sin polémica que el cine es un arte visual, no porque no incluya elementos sonoros sino porque lo visual tiene preponderancia por sobre lo sonoro. Es admisible una película cuyas imágenes no fueran acompañadas por ningún sonido, pero sería difícil juzgar como película una hora y media de sonidos con una pantalla negra.

Pero sería un error considerar que la imagen y el sonido van por vías incomunicadas. Desde los comienzos del cine, también la imagen visual de las películas mudas variaba según los sonidos que la acompañaran. En esto, el cine parlante no se diferencia del de la etapa anterior. Como bien señala Laurent Jullier, en 1927 no se inventa el sonido sincrónico, como suele creerse, sino que se estrena el primer largometraje de ficción con sonido. Ya desde fines del siglo XIX existían técnicas para tener sonido sincrónico, no sólo con actores que pronunciaban los diálogos desde atrás de la pantalla del cine, sino también con numerosos artefactos que incorporaban herramientas para reproducir los sonidos que acompañaran a las imágenes (con el único inconveniente de que a los pocos minutos sonido e imagen se desincronizaban) (Jullier, 2007, p.7). En el cine de todas las épocas, entonces, la imagen que se observa en la pantalla parece cambiar según la acompañe una música de violines, o bien un conjunto de sonidos que corresponderían a los objetos filmados, o bien una voz que se emite al mismo tiempo que los labios que se mueven, etcétera. Esto no se diferencia demasiado de lo que pretendía con sus experimentos Lev Kuleshov, uno de los primeros cineastas soviéticos. El llamado "efecto Kuleshov" iluminaba la importancia que tenía el montaje para la construcción de sentido en una película: un mismo plano del actor Ivan Mozzhukhin era colocado junto a los planos de un plato de sopa, el cadáver de una niña y una mujer semirrecostada; según Kuleshov, al modo de un Pierre Menard cineasta, este montaje haría ver sucesivamente en el rostro "idéntico" de Mozzhukhin los estados de hambre, dolor y deseo. ¿Qué tipo de relación existe entonces entre la imagen visual y el sonido que se emite en simultáneo? ¿En qué relación entran la música, los sonidos, los ruidos, los diálogos, etcétera, con las imágenes que se proyectan sobre la pantalla? De los elementos de la banda sonora, es la música el que más problemas presenta. Tanto las voces como los sonidos no musicales, desde la lógica perceptiva dominante, corresponden a -aparecen como emitidos por- objetos (entre estos, personas) que interactúan en la pantalla. En los diálogos, el sentido es fijado por lo que las palabras dicen, o por el modo en que son dichas; en el caso de los objetos dentro o fuera de campo que producen sonidos, éstos aparecen o bien como detalles sin importancia o bien como un índice de "otra cosa", que sin embargo hace preguntarse por la fuente de ese sonido. En el caso de El artista, puede citarse como ejemplo la pesadilla del protagonista, estrella del cine mudo, que al apoyar su vaso escucha un sonido.

Extrañado, vuelve a apoyarlo, y ve que el sonido de "vaso apoyándose" coincide con el vaso siendo apoyado. Lo 
mismo sucede con los elementos de su camarín. Empieza a escuchar un murmullo, ruidos de vehículos, rumores de conversaciones, el ladrido del perro, el teléfono, la silla cayendo; pero no puede oír su voz, por más fuerte que grite.

Laurent Jullier aplica a los sonidos del cine la clasificación sígnica de Charles Peirce. Así, distingue entre tres fases de acción de los sonidos: una primaria según la cual los sonidos nos sacuden, "provocan una impresión en nosotros, nos cautivan o asustan, nos mecen o nos perturban, exigiendo una apreciación estética que a veces nos cuesta formular"; una fase "más útil", donde "los sonidos cumplen una función de índice y señal; nos aportan informaciones sobre la fuente que los produce (...) y sobre el espacio que transitan"; finalmente, en la tercera fase, la más sofisticada, "Ios sonidos revisten la función de símbolos y remiten a sistemas de signos codificados, entre los cuales los más usados son el sistema verbal y el sistema musical" (Jullier, 2007, pp. 42-43). Sin embargo, es preciso distinguir, dentro de esta fase "sofisticada", entre la música y los diálogos. A diferencia de esos sonidos referentes a objetos y de los diálogos, en el caso de la música, en todos sus modos de aparición (como música extradiegética o diegética, como emitida por una fuente presente o ausente en la pantalla, etc.), y debido a su polisemia, el sentido no se agota ni en lo que "significa" ni en la fuente que la produce. Parece haber algo más que ancla fuertemente la música de una película a la imagen proyectada. Por supuesto, la distinción entre música, diálogos y ruidos podría ser anulada desde otro punto de vista. Por ejemplo, podría pensarse a la banda sonora, con todos sus elementos, como una gran partitura. Alex Ross cita una anécdota según la cual Arnold Schoenberg, convocado en 1934 para poner música a una película de Hollywood, pretendía tener bajo control todos los elementos sonoros de la película, incluyendo las palabras pronunciadas por los actores. Esto es, hasta la altura de los sonidos emitidos en las palabras habladas deberían estar bajo control del compositor, para hacerlas jugar con la música de forma más completa (Ross, 2010, pp. 372-373). Esta pretensión de Schoenberg es el germen de lo que ya se había plasmado en el Sprechgesang o "canto hablado" (piénsese en un ejemplo más actual: el rap). La música concreta, por su parte, utiliza como insumo sonidos que en una película pertenecerían al campo de los objetos, no de la música extradiegética. La película (Untitled) es a este respecto un ejemplo privilegiado: su protagonista es un "músico concreto", y la banda sonora abunda en sonidos que reconoceríamos habitualmente como emitidos por objetos cotidianos, pero utilizados como parte de la música extradiegética, es decir, sin hacer referencia al objeto emisor del sonido.

\section{Capítulo III}

Es preciso decir que el problema de lo musical y lo extramusical está planteado aquí en términos cinematográficos. Pero son los términos con que el cine adaptó a su ámbito un problema mucho más antiguo: el del significado de la música, el de si la música tiene relación con o puede producir una imagen -en sentido amplio- que no sea ella misma. En el cine más difundido actualmente, la persistencia de viejos clichés cumple con las funciones que más comúnmente se ha dado a la música en el cine: un refuerzo de lo que se pretende que la imagen visual dice por sí misma. Pero este refuerzo no es más que un intento de anular otra polisemia, la de la imagen visual que, como había mostrado Kuleshov, dista mucho de tener un sentido unívoco. Basta ver a lo que quedarían reducidas algunas de las escenas más famosas del cine mundial sin la banda sonora que las acompaña (piénsese por ejemplo en el cuchillo de Psicosis de Hitchcock). Este uso proviene de la facilidad con que la música "armoniza" los cortes entre imágenes. El uso de una sola canción, por ejemplo, que siguiera sonando a lo largo de varias escenas diferentes, unificaría imágenes que con otra banda sonora aparecerían quizás inconexas (el lector puede hacer la prueba fácilmente, además de acceder a cualquier clip realizado de forma casera en Youtube). Aquí radica la pobreza de muchos videoclips: al menos en un nivel general, cualquier 
combinación de imágenes "encaja" con cualquier canción, dado que es esta unidad de la música la que da coherencia al conjunto (el caso inverso - una misma toma con muchas canciones en sucesión- tendría un efecto bien diferente). "La música es (...) un flexibilizador del espacio y del tiempo" (Chion, 1993, p.83). En El artista esta "ventaja" de la música es aprovechada en varias ocasiones; el ejemplo más evidente de esto es la música de jazz que recorre el trabajo de Dujardin como director de su propia película, o la que simboliza el ascenso de Peppy Miller; es la música la que da el "aire" de ligereza al montaje de imágenes. El sonido, continúa Chion, "sigue siendo lo que nos hace ver en la pantalla lo que él quiere que veamos en ella" (Chion, 1993, p.137). Como ya se dijo, este aspecto de la música, que la distingue de la imagen, no es novedoso cuando el cine la hereda como problema a pensar. Ya Platón, en sus Leyes, afirmaba que las creaciones de la música son la imitación y la representación de un objeto reproducido (cf. 668b,c,d). En los libros II y III de su República se afirma que ciertas armonías "equivalen" a estados del alma. Por ejemplo, los modos lidio mixto y lidio tenso serían tonos quejumbrosos; a la debilidad y a la embriaguez corresponderían las armonías jónicas y lidias. Son necesarias únicamente dos armonías: una "que pueda imitar dignamente los sonidos y las modulaciones de un hombre valiente", y "otra melodía para imitar al hombre que toma parte en una acción pacífica y no violenta sino voluntaria" (399b-c). Esta línea genealógica seguirán quienes, especialmente en los siglos XVII y XVIII, postulen una retórica musical en donde lo verbal se aplique, dominándolo, a lo musical. Y el debate llegará vivo hasta el siglo XIX, expresado en un texto de Friedrich Nietzsche: "Sobre la música y la palabra", de 1871. Para Nietzsche, el único objeto que puede tener la música es el mundo de la Voluntad (concepto que toma de Schopenhauer); el mundo de las imágenes (el de las palabras) y el de los sonidos "están demasiado lejos el uno del otro para poder tener más que una relación meramente exterior; el canto es sólo un símbolo y está con la música en la relación de los jeroglíficos egipcios de la valentía con los valientes guerreros" (Nietzsche, 1871). El polémico último movimiento de la Novena sinfonía de Beethoven, donde la impureza de la palabra aparece sobre la pureza de la música, será un campo de batalla privilegiado:

Todo aquel alto vuelo, aquella sublimidad de los versos de Schiller, no hace sino estorbar, incomodar y hasta ofender a la ardorosa melodía popular de la alegría; pero como el creciente desarrollo de los coros y de las masas orquestales nos impide oírla, no sentimos la incongruencia (Nietzsche, 1871).

Esto es, si hay que defender la colocación de los versos de Schiller en la sinfonía es precisamente porque no se comprenden como versos, sino como sonidos no lingüísticos. En el siglo XX, Arnold Schoenberg también abordará el problema al hablar sobre algunos lieder de Schubert:

cuando hube leído los poemas [en que se basaban dichos lieder] saqué la conclusión de que con ello nada había conseguido para aumentar la comprensión de las canciones, ya que no me hicieron cambiar en lo más mínimo mi concepción sobre la interpretación musical. Por el contrario, parecía que, sin conocer el poema, yo había captado el contenido -el contenido real-y quizás de manera aún más profunda que si me hubiera aferrado a la simple superficialidad de los pensamientos expresados por palabras" (Schoenberg, 1974, pp. 2829).

\section{Capítulo IV}

¿Cuál es, a grandes rasgos, la utilización de la música que lleva a cabo El artista? Prácticamente durante toda la película se echa mano de esquemas musicales ya difundidos y digeridos por el público cinematográfico. Por ejemplo, la música que parece querer generar tensión cuando el protagonista se dirige a los estudios 
cinematográficos en su automóvil; es la música la que nos hace esperar algo negativo, y no la configuración de las imágenes. O bien cuando, en ocasión del desastre económico de George Valentin, aparece una música similar a la que utilizan los noticiarios en la televisión cuando se proponen conmover a su audiencia: una suave melodía ejecutada lentamente por un piano, que aporta lo suyo a las miradas meditativas del protagonista ( ¿o es la música la que le da a la imagen ese carácter meditativo?). Cuando el espíritu de la escena es más sosegado, la música elegida está en tono mayor, sin disonancias, como evitando cualquier atisbo de tensión. En El cine y la música, Theodor Adorno y Hanns Eisler escribían:

La producción masiva de films ha conducido a la creación de situaciones típicas, momentos emocionales repetidos, a la estandarización de los recursos para estimular la tensión. A esto corresponde la creación de lugares comunes musicales. La música suele entrar a menudo en acción precisamente cuando en virtud del "estado de ánimo" o de la tensión se intenta conseguir efectos especialmente característicos (Adorno y Eisler, 1976, pp. 31-32).

De este modo, la música de El artista se limita a funcionar como esquema de la sucesión de las acciones; la música que se escucha va describiendo e hilando las escenas con elementos que la imagen no puede mostrar. Aunque es preciso decir que esta "música en off" (que Michel Chion define como "música de foso"1) que no aparece ni pretende aparecer en primer plano no autoriza, por supuesto, a tomarla como síntoma de una película poco valiosa. De hecho, es poca la cantidad de directores que den a su banda sonora un tratamiento complejo (Marguerite Duras, Jean-Luc Godard, por nombrar algunos ejemplos). Según Laurent Jullier, existen tres grandes categorías estilísticas según las cuales clasificar el uso que las películas hacen de la música: clasicista, moderna, posmoderna. La primera "supone utilizar una música al servicio de la transparencia del relato"; "la modernidad prefiere mantener al espectador a distancia, hacerle consciente del hecho de que le están contando una historia"; la posmodernidad, por último "pone la música al servicio de la producción de vértigo y del «baño de sonidos»" (Jullier, 2007, pp. 48-49). Desde esta clasificación, El artista es sin lugar a dudas parte del paradigma clasicista. Y lo es apelando a las convenciones más difundidas del cine industrial, y de la música que acompaña dicho cine. La banda musical del film está compuesta de ritmos regulares, previsibles. Igual de previsibles son los movimientos armónicos y melódicos de los instrumentos: si la trama está por dar algún vuelco que hay que remarcar, la armonía tenderá hacia intervalos tonalmente tensionantes, que se resuelven (tonalmente) si la situación narrada lo hace.2 De este modo, más allá de la valoración que hagamos del modo en que se narra la historia, e incluso del "gesto" que supone presentar una película de estas características, el problema principal de El artista es que la música, gracias a su omnipresencia -debida al hecho de tratarse de un "film mudo"-, se convierte en un elemento demasiado esencial de la obra; y al no estar sometida a un tratamiento que supere los lugares comunes más habituales del mainstream cinematográfico, convierte a toda la película en un producto que sólo se centra en el "hilo" argumentativo, despreciando uno de los elementos más importantes para la coherencia en la sucesión de las escenas.

\section{Capítulo V}

Puede ser útil, en este desarrollo, el aporte de Michel Chion sobre lo que llama el "valor añadido" de un sonido respecto de una imagen: Por valor añadido designamos el valor expresivo e informativo con el que un sonido enriquece una imagen dada, hasta hacer creer, en la impresión inmediata que de ella se tiene o el recuerdo que de ella se conserva, que esta información o esta expresión se desprende de modo "natural" de lo que se ve, y está ya contenida en la sola imagen. Y hasta procurar la impresión, eminentemente injusta, de que el sonido es 
inútil, y que reduplica la función de un sentido que en realidad aporta y crea, sea íntegramente, sea por su diferencia misma con respecto a lo que se ve (Chion, 1993, pp. 16-17).

Este aspecto de la música, es decir, el hecho de que tenga la capacidad de adaptarse "armónicamente" con una infinidad de imágenes, al mismo tiempo que ninguna imagen puede ser deducida necesariamente de una música, es el que la vuelve tan problemática a la hora de pensar la relación entre música e imagen. No existe una relación unilineal que haga derivar, de una música dada, una única imagen que le correspondería. De hecho, es preciso incluso preguntarse si es necesario que la música produzca alguna imagen. El término "imagen" puede ser algo confuso. Es conveniente por eso ponerla en relación con otro término problemático: el de "representación". Podemos contraponer la música a la imagen, en cuanto cuando hablamos de imagen lo hacemos en general pensando en una imagen visual. Esta relación entre la música y la representación puede ser rastreada hasta Schopenhauer. En El mundo como voluntad y representación, Schopenhauer describe a la música como una especie de lenguaje universal, pero independiente del mundo de los fenómenos; la música nunca expresa el fenómeno sino solo la esencia interior, el en sí de todo fenómeno, la voluntad misma. De ahí que no exprese esta o aquella alegría particular y determinada, esta o aquella aflicción, dolor, espanto, júbilo, diversión o sosiego, sino la alegría, la aflicción, el dolor, el espanto, el júbilo, la diversión y el sosiego mismos, en cierto sentido, in abstracto; expresa su esencia sin accesorio alguno y, por tanto, sin sus motivos. Sin embargo, la comprendemos perfectamente en su quintaesencia abstraída (Schopenhauer, 2003, pp. 317-318).

Deudor de una metafísica tan antigua como la que denuncia, para Schopenhauer la música es diferente al resto de las artes precisamente porque no copia el mundo fenoménico, sino que "representa lo metafísico de todo lo físico del mundo, la cosa en sí de todo fenómeno". Es por esto que "la música resalta cualquier pintura y hasta cualquier escena de la vida real y del mundo, incrementando su significación" (Schopenhauer, 2003, p. 319). Las palabras, las imágenes, en fin, todos estos modos de expresión no están nunca vinculados ni se corresponden con ella [con la música] de forma absolutamente necesaria, sino que tienen con ella la simple relación de un ejemplo cualquiera con un concepto general: representan en la determinación de la realidad lo que manifiesta la música en la universalidad de la mera forma (Schopenhauer, 2003, p. 319).

Estas conceptualizaciones fueron desarrolladas años más tarde por un joven Nietzsche, lector y admirador de Schopenhauer. En El origen de la tragedia (cuyo título original era el sugestivo El origen de la tragedia en el espíritu de la música) la oposición ya no se da entre los mundos de la voluntad y de la representación, sino entre dos principios que regulan el desarrollo de la vida artística para Nietzsche: lo apolíneo y lo dionisíaco. Pero a diferencia de Schopenhauer, en Nietzsche estos dos principios coexisten permanentemente, en un constante estado de discordia y precisando uno del otro. Para Nietzsche, la imagen se corresponde con la palabra, con el concepto, mientras que la música se diferencia de esas imágenes individualizadas. Así, el lirismo es tan absolutamente dependiente del espíritu de la música misma, en su plena libertad, como la música misma es independiente de la imagen y de la idea; no tiene necesidad de ellas, las "tolera" no más, al lado de ella. La poesía del artista lírico no puede expresar nada que no esté ya contenido, con la más extraordinaria universalidad y perfección, en la música que le obliga a esta traducción de imágenes (Nietzsche, 2007, pp. 7576).

Es por esto que, volviendo a El artista, la utilización permanente de clichés acerca de lo que sus músicas "representan" (violines o piano para el amor o la melancolía, sonidos graves para generar tensión, etcétera) podría ser criticada precisamente por dejar incuestionada esa relación entre el sonido en su especificidad 
musical y aquello que - de forma natural o no- ese sonido representaría más allá de sí mismo. La banda sonora de El artista es una banda sonora que apuesta por lo ya dado, que en ningún momento toma a su cargo el riesgo de cuestionar los "efectos" que, se supone, producen determinadas músicas en los oyentes. Su música se vale de convenciones ya asentadas en la música de cine, es decir, que ya han sido probadas como "eficaces".

\section{Capítulo VI}

Sin embargo, el cine y la música no siempre se han limitado, como sí hace El artista, a evitar las problemáticas que surgen de la relación entre lo sonoro y lo visual. Como afirma Gilles Deleuze en sus estudios sobre cine, y a partir de los trabajos de Balasz y Chion, la aparición del sonido sincrónico implica un cambio radical respecto de la música que acompañaba a los filmes silentes. Con el sonido, la imagen gana una cuarta dimensión: "Es probable entonces que el cine sonoro modifique la imagen visual" (Deleuze, 2005, p. 299). Desde este punto de vista, entonces, El artista aparece empobrecida por haber renunciado -o más bien, por haber creído que se podía renunciar- a esa cuarta dimensión que los largometrajes sonoros trajeron consigo. Al pretender su banda sonora imitar la música que acompañaba a las películas mudas, el film de Hazanavicius sigue presa de la necesidad de que la música se corresponda con la imagen visual, evitando la "emancipación" y el mayor desarrollo del componente sonoro (Deleuze, 2005, p.314). Queda abandonado así el trabajo sobre ese "valor añadido" al que se refería Michel Chion.

Ese enriquecimiento de la imagen por parte del sonido es recíproco:

si el sonido hace ver la imagen de modo diferente a lo que esta imagen muestra sin él, la imagen, por su parte, hace oír el sonido de modo distinto a como éste resonaría en la oscuridad. Sin embargo, a través de esa doble ida-y-vuelta, la pantalla sigue siendo el principal soporte de esta percepción. El sonido transformado por la imagen sobre la que influye reproyecta finalmente sobre ésta el producto de sus influencias mutuas (Chion, 1993, p. 31).

En el capítulo nombrado, Deleuze acude a Hanns Eisler, músico que ya hemos citado y que junto con Theodor Adorno ha aportado numerosos conceptos a la discusión. En ese texto escrito en común, y al momento de trabajar la cuestión de la "ilustración musical", los dos autores proponen casi irónicamente que se la someta a una veda temporal o a un uso prudentísimo. Es que, explican, los esquemas de asociación (por los que aprendimos a relacionar cierto tipo de melodía, de ritmo, de armonía, o cierto tipo de instrumento, con un elemento del "afuera") están ya tan difundidos que la música "hace ya mucho tiempo que no «ilustra» nada, sino que solamente sirve para despertar automáticamente la idea" que se quiere ilustrar (Adorno y Eisler, 1976, p. 28). Esta paradoja se da también cuando lo que se quiere representar mediante la música no es un objeto, un paisaje, un país, sino un sentimiento o una expectativa. Las siguientes líneas parecen escritas para El artista:

La música suele entrar a menudo en acción precisamente cuando en virtud del "estado de ánimo" o de la tensión se intenta conseguir efectos especialmente característicos. El pretendido efecto se frustra, porque el recurso se ha hecho familiar a través de innumerables situaciones análogas. Elfenómeno tiene un doble sentido psicológico: si la imagen muestra una apacible casa de campo mientras la música emite los acostumbrados sonidos siniestros, el espectador sabe en seguida que va a pasar algo terrible. El anuncio musical refuerza la tensión, pero simultáneamente la destruye a través de la certeza de lo que se avecina (Adorno y Eisler, 1976, pp. 31-32). 
Teniendo en cuenta estos aportes puede afirmarse que, dado que lo visual y lo sonoro son irreductibles entre sí, serán interesantes a este respecto aquellas obras de arte que, al cuestionar la relación entre música e imagen, no oculten el movimiento de ida y vuelta entre -en términos deleuzeanos- lo molecular y lo molar, entre lo ya individuado y lo preindividual. Las obras audiovisuales que podrían levantarse como ejemplo frente a las dificultades de El artista son las que permiten repensar el proceso por el cual la música se desprende de su pretendida pureza para individualizarse en "imágenes" que representan algo exterior a ella misma, es decir, para "significar".

\section{Capítulo VII}

Tal ha sido la tarea de algunas de las vanguardias musicales del siglo XX, que han colaborado con sus propios medios con el problema que el cine deja entrever en su carácter audiovisual. Gran parte de las revoluciones musicales del siglo $X X$ han surgido como respuestas a la pregunta acerca de lo que la música representa, $\mathrm{e}$ incluso de si la música representa o debería representar alguna cosa en absoluto. A partir de los siglos XVI y XVII, con la intensificación de la racionalización de la producción musical, se instala como cuestión central la pregunta acerca de si la música es o no significativa. Teóricos como Gioseffo Zarlino, más centrados en el aspecto armónico de la música, son los padres de lo que luego se llamó música "pura", "absoluta": esto es, desligada de cualquier objeto externo al sonido mismo. Otros, como Claudio Monteverdi, privilegiaban la melodía por sobre la armonía y abogaban por el predominio del elemento vocal por sobre lo instrumental; la música (esto es, la armonía) está para acompañar al significado de las palabras. Será a partir de esta disyuntiva -las combinaciones de sonidos como algo cerrado en sí mismo, o como un acompañamiento de una significación trascendente- que se definirán todas las concepciones futuras del significado de la música. A partir del siglo XVIII -y la influencia de Schopenhauer no es menor- la música aparece como el arte más elevado a partir del criterio que antes se usaba para despreciarla: la dificultad o imposibilidad de delimitar firmemente su significado según el lenguaje cotidiano, eso que se elogia en El mundo como voluntad y como representación. La música, en un claro anticipo del romanticismo, es ahora el lenguaje de los sentimientos, de esos afectos que el lenguaje verbal siempre recorta cada vez que intenta describirlos. A partir del romanticismo, la música tendrá en las cuestiones expresivas su elemento fundamental. Cada vez más, los músicos ya no se ciñen a las formas clásicas para "llenarlas", sino que empiezan a elaborar sus propios criterios a partir de los cuales deberán evaluarse sus composiciones. Con la música de Schoenberg y de sus discípulos, ya no sólo está en tela de juicio la "significación" de la música, sino que se derrumban los criterios (básicamente, el mundo tonal) a partir de los cuales se había juzgado la música desde el barroco. En síntesis, la música se va liberando de la obligación de tener una referencia externa; el mundo de los objetos, de las imágenes, se desliga así del mundo sonoro. Quizás esta revolución ya esté en el primer Nietzsche, para quien el sentido privilegiado debe ser el oído, y no la vista. Esta emancipación de la música respecto del mundo de los objetos será retomada luego por diversos autores a lo largo del siglo XX. Adorno y Eisler, por ejemplo, escriben que La música, por muy definida que sea atendiendo a su forma particular de composición, no es jamás definida respecto a un objeto externo en relación a ella que tratase de expresar o imitar. A la inversa, ninguna imagen, ni siquiera una imagen abstracta, está completamente emancipada del mundo de los objetos (Adorno y Eisler, 1976, p. 92).

En términos similares, para Lévi-Strauss la diferencia entre música y pintura, entre un arte sonoro y un arte visual, radica en el hecho de que mientras la pintura trabaja con colores - que "son dados antes de ser utilizados" (Lévi-Strauss, p. 28)- la música lo hace con sonidos musicales, que no existen originariamente en la naturaleza, en el mundo del afuera. Los colores son equivalentes no de la nota musical sino de los ruidos: 
ambos poseen un alto índice de referencialidad. Volviendo por última vez a El artista, creo que aquí radica la pobreza de su banda sonora: en la asociación incuestionada e unilineal de determinadas características sonoras (instrumentación, armonía, ritmo, etcétera) al mundo cotidiano de los objetos. Renuncia pues a entender la percepción visual de imágenes característica del cine como algo paradójico y sinestésico, como una visión siempre contaminada de otros sentidos.

En este sentido, quiero rescatar una escena muy valiosa de la película, que va a contramano de lo criticado anteriormente: sobre el final del film, sin saber que Peppy Miller está yendo en ese mismo momento a buscarlo en su automóvil, el desesperado protagonista acerca un revólver a su cabeza y parece dispuesto a disparar. Aparece entonces en intertítulo ¡Bang!, y la música se detiene, quedando las imágenes acompañadas de silencio. Sin embargo, en el cuadro siguiente el espectador se da cuenta de que no es el arma sino el choque del automóvil contra un árbol lo que produjo la onomatopeya. En esta escena aparece la inevitable interpenetración entre la imagen, la música, las palabras y los ruidos. Sin embargo, en líneas generales, El artista no cuestiona de ningún modo el sentido común del espectador cinematográfico, y se limita a reproducir lo ya visto, lo ya escuchado.

Si en las vanguardias musicales puede hallarse alguna experiencia política, ésta radica en el hecho de pensar a la música como algo no subordinado a lo que representa, esto es, a un plano trascendente que deje a lo sonoro en segundo lugar. Trabajar sobre lo audible nos despega de la objetualidad cotidiana, nos da otro acercamiento al mundo, hace tambalear la firmeza de la ontología definida a partir de lo visual. Frente a lo que propone El artista, será preciso indagar en esas prácticas artísticas que tanto en cine como en música pretenden desautomatizar los regímenes de percepción dominantes, que no niegan ingenuamente toda relación entre música e imagen (entre la música y un "afuera"), sino que afirman esa relación como múltiple, relaciones con las que el artista trabaja, cita, deshace, recompone, juega, anula, cumple y decepciona expectativas...

\section{Notas}

1. "Llamaremos música de foso a la que acompaña a la imagen desde una posición off, fuera del lugar y del tiempo de la acción. Este término hace referencia al foso de la orquesta de la ópera clásica. Llamaremos música de pantalla, por el contrario, a la que emana de una fuente situada directa o indirectamente en el lugar y el tiempo de la acción, aunque esta fuente sea una radio o un instrumentista fuera de campo." (Chion, 1993, p.68)

2. Por otra parte, hay en la banda sonora -premiada en 2012 con un Oscar a la mejor banda sonora- dos citas reconocibles: la primera, una composición de Bernard Herrmann para el film Vertigo (1958), de Alfred Hitchcock; la segunda, la Danza del trigo de Ginastera, perteneciente a su ballet Estancia.

\section{Referencias Bibliográficas}

Adorno, T.; Eisler, H. (1976). El cine y la música. Madrid: Fundamentos.

Chion, M. (1993). La audiovisión. Introducción a un análisis conjunto de la imagen y el sonido.

Barcelona: Paidós.

Deleuze, G. (2005). Estudios sobre cine 2. La imagen-tiempo. Buenos Aires: Paidós. 
Jullier, L. (2007). El sonido en el cine. Barcelona: Paidós.

Lévi-Strauss, C. (2010). Mitológicas. Lo crudo y lo cocido. Buenos Aires: Fondo de Cultura Económica.

Nietzsche, F. (2007). El origen de la tragedia. Madrid: Austral.

(1871). "Sobre la música y la palabra". Disponible en: http://es.Scribd.Com/doc/7145377/ friedrich-nietzschesobre-la-musica-y-la-palabra.

Ross, A. (2010). El ruido eterno. Escuchar al siglo xx a través de su música. Madrid: Seix Barral.

Schoenberg, A. (1974). El estilo y la idea. Madrid: Taurus.

Schopenhauer, A. (2003). El mundo como voluntad y representación. Madrid: Trotta.

La música y la imagen. Anotaciones a partir de El Artista fue publicado de la página 103 a página115 en Cuadernos del Centro de Estudios de Diseño y Comunicación № 54 